American Journal of Economics and Business Administration 1 (2): 138-140, 2009

ISSN 1945-5488

(C) 2009 Science Publications

\title{
Evaluating Experiential Learning in Organizational Behavior: Taking Measure of Student Perception Regarding Group Experience
}

\author{
Roxanne Helm-Stevens and Orlando Griego \\ School of Business and Management, Azusa Pacific University, \\ 901 East Alosta Avenue, Azusa, CA, USA
}

\begin{abstract}
Problem statement: The purpose of this study was to determine undergraduate student perceptions in the areas of group experience within the context of an undergraduate organizational behavior business class community service assignment. College students, as part of an in-class servicelearning project, were assigned to teach business related curriculum to at-risk high school students.

Approach: Students, enrolled in the required senior level business course, were then assessed in the following areas: service learning experience and group experience. A multiple-choice questionnaire was administered to undergraduate students in an organizational and administrative behavior class and analyzed for correlations and relationships. The survey was administered in week eleven of a traditional semester and in the last week of the community service project. The survey was comprised of seven questions relating to group experience and one based on the impact of the community service project itself. Results: Significant findings revealed a positive correlation between the group experience and the feelings toward the project. In addition, multiple linear regressions suggested a positive and significant prediction. Conclusion: From the findings, implications for the development of experiential learning projects for use in the college classroom will be discussed. When paired with the results of previous research, the findings of this research can be very useful in developing group based service learning projects at the undergraduate level. Based upon the importance of service learning as an experiential teaching style, it is critical to understand how to better use this vehicle for discovery.
\end{abstract}

Key words: Service learning, experiential learning, undergraduate curriculum

\section{INTRODUCTION}

Prior research: Experiential learning involves any type of teaching that calls upon relevant life and learning experiences and a reflection of the past in order to create deeper understanding ${ }^{[2]}$. Service learning and colearning are aspects of experiential learning that combines community service projects with credit bearing educational experience ${ }^{[4]}$. VanWynsberghe and Andruske ${ }^{[9]}$ describe this method as "the place where education meets the community".

Numerous studies have identified a wide range of benefits regardless of what term is used to describe this style of learning. These benefits include the personal and social development of students ${ }^{[5]}$; community engagement ${ }^{[8]}$; increased ability to think creatively, engage in group discussion, lead a group, go beyond the textbook to find answers, communicate with others and know whom to contact to get things done ${ }^{[4]}$; as well as written and oral communication skills, commitment and work ethic, teamwork and team skills, cultural awareness and sensitivity to diversity ${ }^{[4]}$.
By narrowing the scope of service learning to undergraduate business classes, the quantity of data is less prevalent, but the results are similar and demonstrate that applications improve the achievement of learning objectives in information systems, management and marketing ${ }^{[1]}$. Researchers also emphasis service learning's practical ability to provide students a direct link to real-world skills, which gives the opportunity to implement and enhance content from the class $^{[4]}$. Papamarcos ${ }^{[7]}$ suggests that service learning may in fact be the most effective tool available for professors in the area of business and he describes it as "a complex, comprehensive pedagogy that requires a dramatic rethinking of the dynamic of learning, from static listening to participatory engagement".

Service learning can be executed in a number of ways and a one of these methods is through group or teamwork. These integrative projects involve assignments based in the community that are much too large for an individual to complete in the given time ${ }^{[8]}$. Group experiences give students the opportunity to

Corresponding Author: Roxanne Helm-Stevens, School of Business and Management, Azusa Pacific University, 901 East Alosta Avenue, Azusa, CA, USA 
increase involvement, deepen understanding and improve thinking ${ }^{[6]}$. Group-based service learning is also known to develop students' ability to work with others and their tolerance for diversity ${ }^{[3]}$. David Jaques $^{[7]}$ suggests that "groups are a valuable vehicle for learning about the skills and concepts of a subject discipline, but are also a way of learning about groups: Developing abilities in cooperative work for later life".

Research question: The purpose of this study was to determine the impact of group experience, specifically in the area of group cohesiveness and personal skill sets for business students at the undergraduate level. We sought to identify the differences and relationships among the following areas: Perception of group experiences and positive feelings toward a service learning experience. Before analyzing the data received in regard to this question, we will describe the student population surveyed in the study and also the type of service learning project in which they were involved.

Description of community service assignment: Students were all undergraduate (juniors and seniors) students at a university located in California, who participated in a community service project for an organizational and administrative behavior class, BUSI 448, a required 400 level business course with a community service component.

The community service component of the class is an 8 week teaching assignment wherein students were assigned to classrooms within the local community. All classrooms are located in high schools in Azusa, California. According to US Census Bureau 2000 ${ }^{[8]}$ profile of general demographic characteristics, the total population of the City of Azusa, CA is 44,172 (49.9\% male and $50.6 \%$ female) with a median age of 27.1 . The race demographics for the City of Azusa are Hispanic/Latino 63.8\%, Not Hispanic/Latino 36.2\% with housing occupancy of $50.5 \%$ owner-occupied versus $49.5 \%$ renter-occupied.

Eighty students were divided into twelve groups (mean group size of six) and assigned to deliver a business-focused curriculum to local junior high and high school students. The age-specific curriculum was provided by the Junior Achievement Academy. Students were responsible for creating group contracts to illustrate their roles and responsibilities, reviewing and organizing curriculum materials, revising lesson plans (creativity was encouraged) and then delivering the lesson plans in various classrooms in the local schools. Classroom assignments remained constant throughout the length of the service learning assignment.
Table 1: Sample questions from the areas of group experience and service learning

Area of focus Sample question

Group experience This class has helped me in dealing with group conflict...

Service learning I believe the service-learning component of this class contributed to my development in understanding the factors of cohesiveness within a team...

For eight of the 14 weeks one class per week was dedicated to time in the classroom and much of the student's grade hinged on their participation and evaluations. Although guidance was available upon request, the students carried a great deal of responsibility in seeing this project to fruition.

\section{MATERIALS AND METHODS}

The method utilized for answering our research question was a survey questionnaire administered to each of the students participating in the class. In was given in a study format with a thorough explanation of the formatting. The survey was administered on November 20, 2007 and $100 \%$ of the students in the class agreed to participate in the study.

The survey was comprised of 13 questions with four addressing confidence in personal skills and ability, seven relating to the group experience and one based on the impact of the service learning project itself. Sample questions from the areas of group experience and service learning are found in Table 1.

Each of the questions utilized a scale for measurement based in experience and opinion. Possible answers included one of the following sets: no experience, very little experience, some experience and extensive experience; or strongly disagree, disagree, agree and strongly agree. The questions were designed to identify their experiences at this point in the course (11 weeks) and the community service project (6 weeks).

\section{RESULTS}

Pearson Correlation tests were run with the data and used to identify the correlations between the group experience and the positive service learning experience. The strongest correlation was found between the group experience and the positive service learning component and it was a positive, significant correlation $(r=0.684$, $\mathrm{p}<0.01)$. The correlation between confidence in skills and positive service learning was also positive and significant $(\mathrm{r}=0.488, \mathrm{p}<0.01)$. The correlation between confidence in skills and group experience was once again positive and significant $(r=0.480, p<0.01)$. 
Multiple linear regression was used to predict group experience against service learning. The results to this test were significant in predicting a positive service learning experience from a positive overall group experience $f(1,54)=44.17, \mathrm{p}<0.01$.

Raw data was also gathered on the gender and ethnicity of each of the participants. We found no significant difference between the male and female gender and no significant difference among the ethnicities of Caucasian, African American, Hispanic, Asian and other.

\section{DISCUSSION}

When paired with the results of previous research, the findings of this research can be very useful in developing service learning programs at the undergraduate level. Previous research confirms the positive impact of service learning in the teaching environment ${ }^{[1,4]}$. Based on the importance of the service learning style of teaching, it is important to understand how to better use this vehicle for discovery.

Jaques $^{[6]}$ suggests that group experiences give students the opportunity to increase involvement, deepen understanding and improve thinking. This theory was confirmed through this study by the positive, significant relationship between group experience and a positive service learning experience. The practical application of the relationship is found in the emphasis placed on group experience by the teacher. Interestingly, confidence in skills is an aspect of classroom teaching upon which most teachers focus, but it may not necessarily be an essential element for a strong service-learning component. Though the skills can be taught in a class, it is the group experience that gives the student an opportunity to apply the information and take away something from the class.

\section{CONCLUSION}

Recommendations: Having realized the significant, positive relationship between group experience and service learning, it is important for professors administering service-learning activities to include opportunities for group growth.

Methods for improving group experience range depending on the type of class and the community service-learning project, but it is essential that group members take ownership in their relationship with their peers and the project itself in order to reach the full learning potential.

Additional research is necessary in order to determine what types of group guidance can be most beneficial. Some of the methods used in this project included instituting a group contract, providing personal and group inventories and giving weekly group feedback.

\section{REFERENCES}

1. Andrews, C.P., 2007. Service-learning: Applications and research in business. J. Educ. Bus., $\quad 83$ : 19-26. http://www.eric.ed.gov/ERICWebPortal/custom/po rtlets/recordDetails/detailmini.jsp?_nfpb=true\&_\& ERICExtSearch_SearchValue_0=EJ778344\&\&ERIC ExtSearch_SearchType_0=no\&accno=EJ778344

2. Barth, M., J. Godemann, M. Rieckmann and U. Stoltenberg, 2007. Developing key competencies for sustainable development in higher education. Int. J. Sustainab. Higher Educ., 8: 416-430.

http://www.eric.ed.gov/ERICWebPortal/custom/po rtlets/recordDetails/detailmini.jsp?_nfpb=true\&_\& ERICExtSearch_SearchValue_0=EJ800447\&ERIC ExtSearch_SearchType_0=no\&accno=EJ800447

3. Dumas, C. 2002. Community-based servicelearning: Does it have a role in management education? Int. J. Value-Based Manage., 15: 249.

4. Govekar, M.A. and M. Rishi, 2007. Servicelearning: Bringing real-world education into the bschool classroom. J. Educ. Bus., 83: 3-10. http://www.highbeam.com/doc/1G1-172524326.html

5. Hunt, R., 2007. Service-learning: An eye-opening experience that provokes emotion and challenges stereotypes. J. Nurs. Educ., 46: 277-281. http://www.ncbi.nlm.nih.gov/pubmed/17580740

6. Jaques, D., 2000. Learning in Groups: A Handbook for Improving Group Working. 3rd Edn., Routledge Falmer, London, ISBN: 10: 0749430915, pp: 320.

7. Papamarcos, S.D., 2002. The "next wave" in service-learning: Integrative, team-based engagements with structural objectives. Rev. Bus., 23: 31-39. http://connection.ebscohost.com/content/article/10 23719843.html; jsessionid=3C5EC48B715EFCF7E B83E35F2648C27E.ehctc1

8. US Census Bureau, 2000. Profile of general demographic characteristics. http://www.census.gov/prod/cen2000/doc/Profiles TD.pdf

9. VanWynsberghe, R. and C.L. Andruske, 2007. Research in service of co-learning: Sustainability and community engagement. Can. J. Educ., 30: 349-376.

http://www.csse.ca/CJE/Articles/FullText/CJE301/CJE30-1-VanWynsbergeAndruske.pdf 